\title{
Architecture of Polish water sports facilities located in parks in the interwar period
}

\author{
Wojciech Kocki \\ https://orcid.org/0000-0002-5954-7735 \\ w.kocki@pollub.pl \\ Department of Architecture, Urban and Spatial Planning, Faculty of Civil \\ Engineering and Architecture, Lublin University of Technology
}

\begin{abstract}
In the interwar period, many sports and recreation facilities were built in Poland. Some of them were located in unique spaces with significant aesthetic and environmental values. One of the examples of such facilities are open swimming pools in the city of Wisła, Ciechocinek and Lviv. Examples of these objects show thoughtful compositional and urban solutions. Such a location of the facilities surrounded by nature was conducive to rest and practicing sports undisturbed by city noise. The location of water sports facilities in parks had many advantages which resulted in better conditions for practicing sports.
\end{abstract}

Keywords: architecture, water sports, interwar period, Lublin

\section{General conditions of water sports architecture}

During the interwar period the trend to locate sports facilities and swimming pools in sports, recreational parks can be observed. These buildings were located in green areas arranged in the form of alleys and squares creating the character of a park space. Additional elements in these spaces were also playing fields, running tracks and gastronomic pavilions. The parks had a good location due to their proximity to the city center. This location made it possible for many residents to reach the park and swimming pool on foot, which encouraged the use of these facilities through easy public access ${ }^{1}$.

\section{Architecture of water sports faclities on the example of Lublin}

\section{Ciechocinek}

One of the most interesting, both architecturally and technically swimming pool built in the interwar period located in the health resort is the brine and thermal swimming pool in Ciechocinek. Based on the example of the construction of a brine and thermal swimming pool in Ciechocinek, which started in 1931 and was put into operation in 1932, the construction methods and construction techniques used in the interwar years can be characterized.

Buildng design in Ciechocinek was created in 1931 by Romuald Gutt and Aleksander Szniolis. A changing room with rounded corners and an arch-shaped roof over the entrance was proposed. The changing room is divided into separate entrances for women and men. Supplementing the spa offer with a sports infrastructure with a bathing area, sports fields, beaches, a brine pool and a small kitchen for children was to complement its attractiveness and generate even more tourists ${ }^{2}$. 
The main structure of the building was a reinforced concrete skeleton filled with silicate blocks and partly with clinker bricks. The floors in men's and women's changing rooms were made of terracotta. The windows were made of steel and the doors as paneled ones in iron frames. Internal, partition walls the toilets are made of glazed bricks. The lower terraces were laid out of concrete slabs with dimensions of $2 \times 2 \mathrm{~m}$ divided by strips of clinker bricks. The dance hall is finished with terracotta.

The pool was designed with dimensions of $100 \times 40 \mathrm{~m}$ and in the shallowest point its width was reduced to $32 \mathrm{~m}$. Around the pool there is a paddling pool with a width of $1.30-2.00 \mathrm{~m}$. The pool is completely divided into three main parts depending on the depth. The shallowest one, intended for children, $0.15-0.90 \mathrm{~m}$ deep and $32 \times 20 \mathrm{~m}$, for adults $0.90-1.50 \mathrm{~m}$ deep and $60 \times 40 \mathrm{~m}$, and for players and athletes, $1.50-3.50 \mathrm{~m}$ deep. dimensions $40 \times 20 \mathrm{~m}$. There were steps leading to the pool, $4 \mathrm{~m}$ wide, and there were ladders to the outside every $20 \mathrm{~m}$. In the vicinity of the deepest part of the pool there is a jump with a reinforced concrete structure $3.0 \mathrm{~m}$ high and two additional trampolines suspended at the level of $1.0 \mathrm{~m}$. Additional elements were reinforced concrete slides, two for children and one, 5 meters for adults. The entire basin was made of reinforced concrete. The bottom is $15 \mathrm{~cm}$ thick and made of reinforced slabs $10 \times 10 \mathrm{~m}$ in size. Around the perimeter of the swimming pool there is a rounded end that allows water to overflow into shallower pools. Water with impurities and suspended solids was discharged through separate channels to the sewage system.
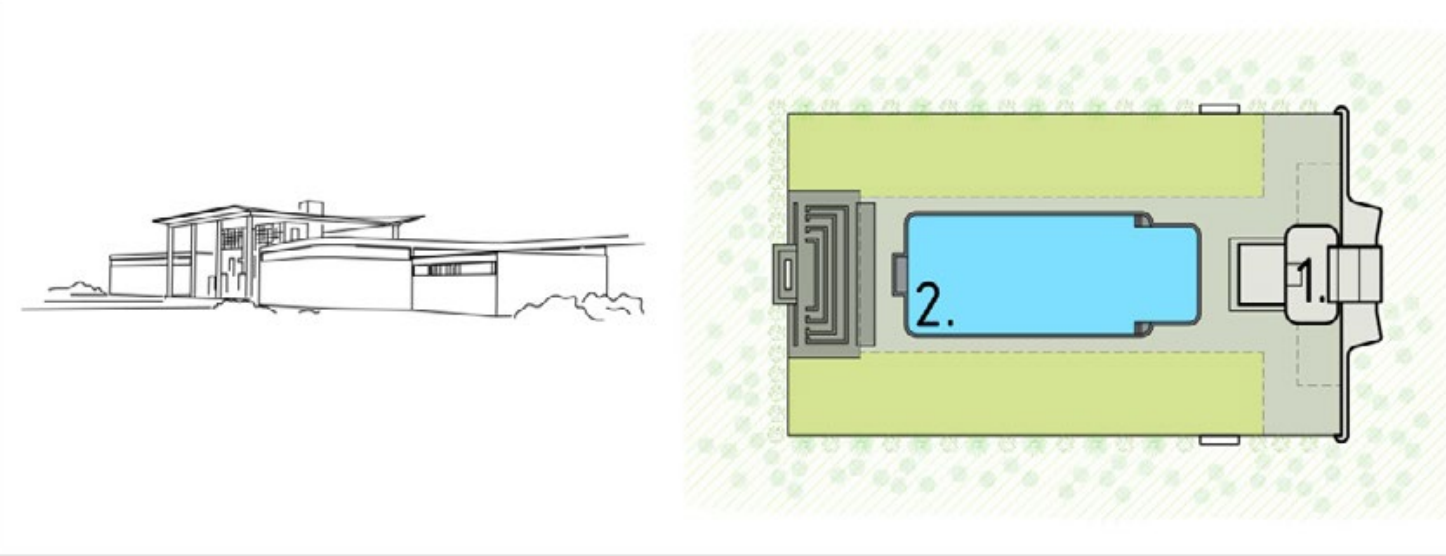

Fig. 1. Situation plan and architecture scheme of Ciechocinek swimming pool, 1. Main building, 2. swimming pool.

\section{Wisła}

An example of modern solutions of sports architecture in the style of modernism was the sports park in Wisła. The architects of the building were E. Zaczyński and S. Tworkowski. The complex included an open-air swimming pool $50 \times 50 \mathrm{~m}$, a shallow pool $30 \times 30 \mathrm{~m}$, paddling pools for children, tennis courts used in winter as ice rinks, restaurants, changing rooms and toilets. A similar facility was also the Medical Center for the Application of the Sun, Air and Movement in Druskininkai. The designers of the building were Edgar Norwerth and Jan Jabloński. Construction plans were also prepared for the Open Air Baths Institute in Katowice, designed by Lucjan Sikorski and Tadeusz Łobos ${ }^{3}$.

The sports park in Wisła, the assumption of the investment, was to strengthen tourism and recreational values, especially when the rank of the village increased after the construction of the President's residence. Wisła, as a city, was developing every year due to the influx of more and more amount of tourists. The infrastructure was systematically expanded and the railway connection was under construction. In the years 1930-1934, a swimming park was created with a reinforced concrete basin and a jumping tower, wooden changing rooms, tennis courts, a beach and a cafe building that also served as an administrative facility and a back room with 
changing rooms for hockey players using the basin in winter. The author of this complex was Stefan Tworkowski. The proper use of the site intended for the construction of the facility was an element that united the sports plan. The two-storey pavilion with lots of glazing and arcades on the ground floor was rated as one of the best examples of the 1930s architecture.

Taking the example of the swimming park in Wisła, it is possible to demonstrate the care for segregating sports and recreational functions in the spatial arrangement of the urban layout. The parks are located along the Vistula River. In the southern part there was a cloakroom complex with the main entrance. The building is divided into three segments connected by a corridor in the northern part of the building. The cloakroom facility is divided into a section for women and men. After leaving the cloakroom to the park, the first area was the areas intended for children. The central part of the park was widened to the east with green areas and a beach. On the west side, by the river, there were open swimming pools divided into a shallower part for non-swimmers and a deeper part for swimmers. In the northern part of the complex, there were tennis courts surrounded by stands on three sides. The function of this court area in winter was turned into an ice rink. In the northernmost part there was an archery track.

In the years of 1934-1936, expansion of the cloakroom facility was planned with additional cloakroom rooms and a cafe.

Among the designed facilities related to water with the function of a swimming pool, open swimming pools were most often designed. At the beginning of the 1930s, about 150 such facilities were built annually, and each year their number was systematically growing. In 1939, more than 350 swimming pools were designed ${ }^{4}$. A large number of such facilities resulted from the relatively high availability in terms of their implementation. They were not cheap and simple in terms of execution, but then their implementation was justified due to the great interest of the public. The indispensable elements of the open-air swimming pools were the pool basin and properly ensured water circulation. The stands were additional elements.

The architecture of the pavilion was designed in a modernist style. The horizontal lines of the building were emphasized by horizontal stripes of windows, cornices and stripes of different façade finishing, both in terms of color and material.

The façade also features a module highlighted by pilaster strips and window divisions. The central part of the building, where the main entrance is located, has been accentuated by a local elevation in relation to the eastern and western wings of the building.

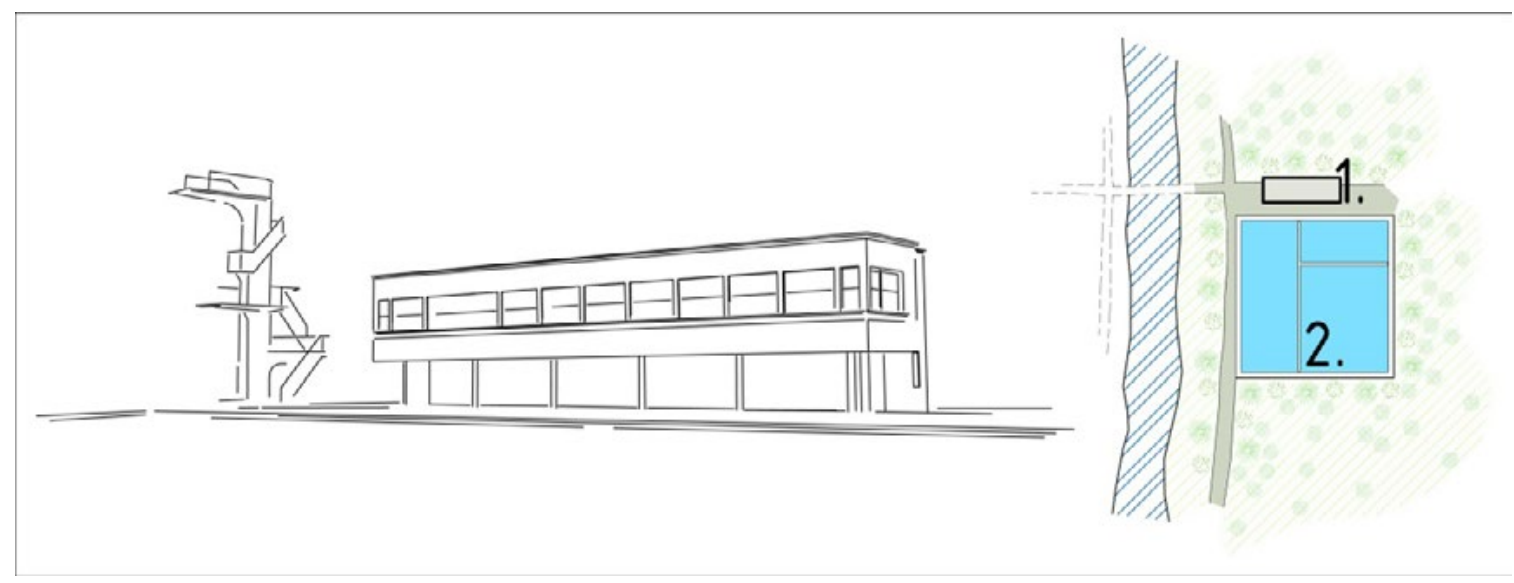

Fig. 2. Situation plan and architecture scheme of swimming pool in Wisła, 1. Main building, 2. swimming pool. 


\section{Lviv}

In the neighborhood of Lviv, the Żelazna Woda park was created, in which there was access to iron-rich waters. In part of the site there was a natural pond called the Kamiński pond ${ }^{5}$. In the years $1935-1938$ a swimming pool was built there according to the design of architect Karasiński and architect Kozakiewicz ${ }^{6}$.

On the example of the Dynamo basin located in the Żelazna Woda Park, one can be observe the characteristic urban layout of individual compositional elements of the larger sports and water facilities. The first element was a cubature building of cloakroom and sanitary facilities, which also had restaurant or cafe rooms. The building was designed as a one-story building with a part of the main hall with increased height. The height was not only different inside, but was also accentuated in the façade, in which glazing with a modular division of several meters was used.

The roof in the central part is designed as hipped, envelope roof, and in the lower part - shed or flat. The second, main element of the complex were the swimming pools divided into users: children, adolescents, amateurs and sportsmen. The basins for various purposes differed in terms of accessibility, method of entry and depth. One of the pool elements that appeared in almost every facility of this type was the jump. The jump was designed and built in a wooden spatial truss structure. In larger swimming pools, the jumps were erected in a reinforced concrete structure. The third compositional element of the park and swimming pool layout were the stands. The seats were designed as wooden benches on brick steps. Currently, the facility is neglected and out of use.
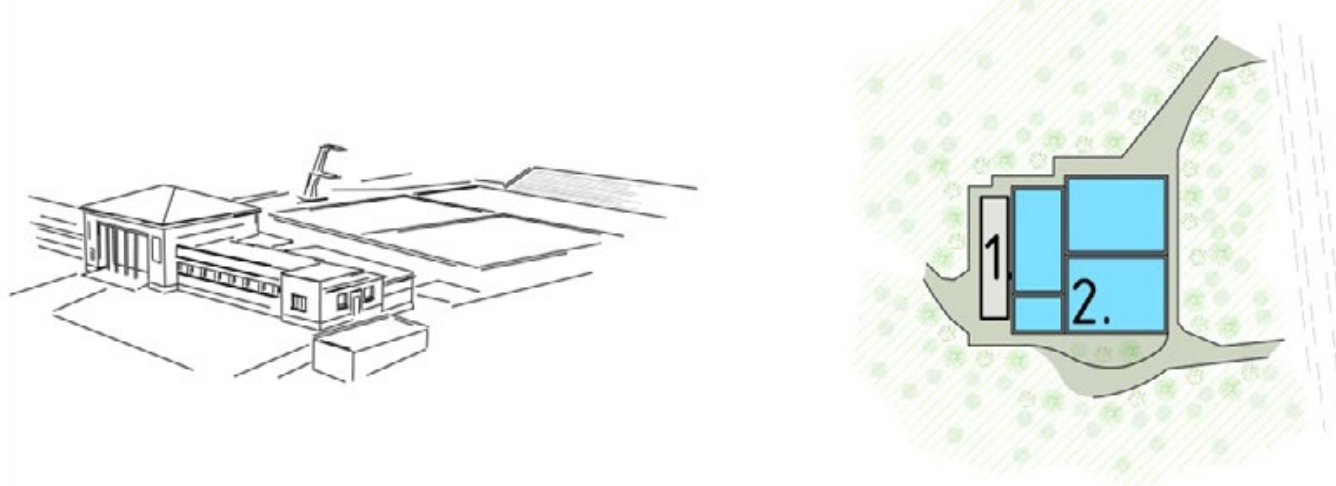

Fig. 3. Situation plan and architecture scheme of Lviv swimming pool, 1. Main building, 2. Swimming pool.

\section{Conclusions}

The location of the swimming pool facilities in sports parks was an opportunity for many residents to use them due to the good location and easy access. Thanks to the location of the pools surrounded by green areas, it created extremely valuable aesthetic values and enriched the impression of being in contact with nature. The location of sports facilities in park areas had many advantages. The area covered with trees, shrubs and grass along with a specially designed arrangement of alleys and public spaces made it possible to rest and created a healthy environment for sports. The examples of projects from Ciechocinek, Wisła and Lviv are one of the most recognizable sports and recreation facilities of the interwar period in the field of water sports. 


\section{Literature}

[1] Kordiak J., Szklane domy, wizje i praktyki modernizacji społecznych po roku 1918, Zachęta - Narodowa Galeria Sztuki, Warszawa 2018. s. 77.

[2] Mały Rocznik Statystyczny 1939, Główny Urząd Statystyczny Rzeczpospolitej Polskiej, Rok X, Warszawa 1939 , s. 20.

[3] Pawlikowska-Piechotka A., Piechotka M., Dzieje obiektów sportowych w Europie, Historia architektury sportowej od czasów starożytnych do współczesności, Akademia Wychowania Fizycznego Józefa Piłsudskiego w Warszawie, Podręcznik akademicki, Warszawa, 2017. s. 261.

[4] Wereszyńska W., Statki na trawie i kropla wody - styl streamline w architekturze $i$ wzornictwie przemysłowym w latach trzydziestych XX wieku w Stanach Zjednoczonych, Europie i Polsce, ARCHITECTURAE et ARTIBUS - 2/2015.

[5] https://www.lwow.info, odczyt: 22-08-2019. 